\title{
The Role of Theory of Truth in Countering Hoaxes Regarding Covid-19
}

\author{
Ria Safitri ${ }^{1}$, Indira Rahmadany ${ }^{2}$, Aliefia Iswanto ${ }^{3}$, and Moses Glorino Rumambo Pandin ${ }^{4 *}$ \\ 1,2,3,4 Faculty of Humanities, Universitas Airlangga, Surabaya, Indonesia \\ Email: ria.safitri-2020@fib.unair.ac.id; indira.rahmadany-2020@fib.unair.ac.id; \\ aliefia.iswanto-2020@fib.unair.ac.id; moses.glorino@fib.unair.ac.id
}

*Corresponding Author E-mail: moses.glorino@fib.unair.ac.id Faculty of Humanities Universitas Airlangga

Jl. Airlangga No.4 - 6, Airlangga, Kec. Gubeng, SBY City, East Java 60115

\begin{abstract}
Indonesia is one of the countries experiencing the COVID-19 pandemic. This causes anxiety for the Indonesian people which makes information about COVID-19 becomes crucial. Objective: This research was conducted with the aim of studying philosophical theories that can play a role in the process of testing information in warding off hoaxes about COVID-19. Researchers want to know whether the theory of philosophy of science can be of assistance to the public in recognizing and rejecting hoax news about COVID-19. Methods: The research was conducted using a descriptive verification method with a qualitative approach. The data from this study were taken from interviews and secondary data was taken by studying the literature. Interview data were taken with the target respondents, namely people in Surabaya with an age range of 25-40 years or what is often referred to as generation $\mathrm{Y}$ or millennials. The criteria for determining the number of respondents were taken until the researcher found a saturated sample. Meanwhile,the literature study data consists of 2 books, 37 articles, 1 website, and 1 report on the results of a national survey. Results: This study found 5 types of theory of truth, namely coherence theory, correspondence theory, pragmatic theory, consensus theory, and performative theory, each of which has a use in identifying hoaxes around COVID-19. Research Recommendation: Further research needs to be conducted which can test the actual practice of applying truth theories in countering hoaxes in the community at a certain scale. Limitations: This research has little chance of being applied by some Indonesians, given their low level of digital literacy and willingness to seek information.
\end{abstract}

Keywords: Philosophy, Philosophy of Science, Hoax, COVID-19, Theory of Truth

\section{INTRODUCTION}

COVID-19 is still a concern in people's lives around the world. COVID-19 or SARS-CoV-2 is a new type of coronavirus with the first infection being discovered at the end of 2019 and has caused a new outbreak in China (Herman, 2021). Since the start of the epidemic in late December 2019, SARS-CoV-2 has spread to all continents with 179,111 cases and 7,426 deaths from WHO data as of March 18, 2020 (Ciotti et al., 2020). The virus can spread through droplets of asymptomatic patients and through aerosols in the health 
environment (Salzberger et al., 2020) with common signs such as respiratory symptoms, shortness of breath, and breathing difficulty until it can lead to pneumonia, severe acute respiratory syndrome, kidney failure, and even death (Abdi, 2020). Due to the rapid spread of COVID-19 with the emergence of many deaths in other countries, the WHO classifies this virus as a pandemic.

With the rapid spread of the virus, Indonesia has become one of the countries affected by the COVID-19 pandemic. The first positive case of COVID-19 in Indonesia was announced on March 2, 2020, which provided information about two people who were proven to have contracted the virus from a Japanese foreign national (Etikasari et al., 2020). This corona virus has spread to provinces in Indonesia, to be more precise, there are 34 provinces (Nursofwa et al., 2020). At first, the Indonesian government did not participate in complying with the methods applied by other countries in relation to the information being shared regarding the COVID-19, namely by taking quick action to socialize the prevention of the virus. This action is based on the government's desire so that the Indonesian people are not anxious about worrying issues, as well as to reduce the existence of fake news or hoaxes from individuals who cannot be held responsible for their actions. In the end, the COVID-19 outbreak has also become something of concern for Indonesian because many people have been affected by the spread of this virus. Therefore, the Indonesian government is trying to decide on a policy lockdown for 14-days to prevent the transmission of the corona outbreak (Yunus and Rezki, 2020). The situation in Indonesia when it was hit by the COVID-19 virus was very concerning. The number of people who do not comply with the rules and protocols that have been set also has a major influence on the rapid spread of COVID-19 (Elgaputra et al., 2020). This can be seen from the increase in the death rate to $8.9 \%$ at the end of March 2020 (Setiati and Azwar, 2020).

\section{The Influence of Hoax on Society}

Hoaxes in Indonesia have long been a scourge of problems in the world of digital literacy. From time to time, fake news or hoaxes always appear, especially when an area is facing a precarious situation. It is possible that the phenomenon of the emergence of invalid news with unclear sources regarding COVID-19 in the midst of public panic will reoccur when Indonesia faces this pandemic virus (Nurislaminingsih, 2020). The high mobility of hoaxes in the community is influenced by easy internet access without being balanced with qualified digital literacy. Digital literacy is an ability that includes technical skills in using information sources and critical thinking about information sources obtained from the internet (Maulana, 2020) while according to Marwuni (2021) digital literacy is digital technology expertise in mastering, analyzing, calculating, controlling, and evaluating data. . With digital literacy, it can be a solution for Indonesian people to avoid believing in hoaxes. However, a survey conducted by KOMINFO in 2020 on the status of digital literacy in Indonesia said that digital literacy in Indonesia was still less than a "good" level. If the highest index score is 5 , Indonesia's digital literacy index is only slightly above 3 . In addition, the rapid spread of hoaxes among the public is also driven by psychological factors. This psychological factor is caused by public panic in the midst of precarious conditions. So, when 
individuals can not think clearly because of panic, they no longer have the will to seek the validity of an information (Harisanty et al., 2021). As a result, all kinds of information are swallowed raw without distinguishing true information from hoaxes and the worst result is misinformation that endangers human lives.

\section{Hoaxes About COVID-19 and its Dangers}

Due to the social restriction policy, all human activities are carried out via the internet (Siste et al., 2020). The existence of the internet can be an effective means for everyone in the world to get information without being hindered by distance, time differences, and geographical factors (Barni, 2020). However, this convenience does not guarantee that all information is correct and acceptable. There are many types of COVID-19 hoaxes that can endanger the health of Indonesians who believe in these hoaxes. To deny hoaxes, Indonesians need to have digital literacy skills. With digital literacy, people will not easily believe hoaxes and will be smart, wise, and responsible in using technology and the internet (Ummah and Kurniawan, 2020). Therefore, Kominfo stated the need for education and digital literacy to the public to prevent the spread and losses of hoaxes (Putri et al., 2020).

It was recorded on the covid19.go.id website, that a chain message had circulated containing information on drug prescriptions for patients with "not too severe" conditions (Official Website for Handling COVID-19, 2021). The details of the drugs in the chain messages are also equipped with the doses that must be consumed, even though each patient may have different symptoms and different side effects if they are not used properly. Misleading news like this does not rule out the possibility of endangering the life of someone who is consumed by false information just because of a lack of checking the validity of the information. Not long ago the first case of COVID-19 in Indonesia was discovered, many Indonesians panicked so much that they could not filter out false information or hoaxes that have become a problem with digital literacy. Written on the site https://www.kominfo.go.id/, hoax news was most widely disseminated on March 24, 2020, which was 10 times (Rahayu \& Sensusiyati, 2020).

The urgency of disseminating information about COVID-19 is of course very important, especially the type of coronavirus that causes COVID-19 in various countries that still require regular studies and prepare the capacity of health facilities (Wardhana, 2020). With the level of urgency in disseminating information about COVID-19, which is very important, it should be balanced with the level of digital literacy of the Indonesian people. In this digital era, people need a good digital literacy to avoid the challenges of digital literacy, one of which is hoax news. News that contains falsehood, deceives, and distorts facts and is made intentionally is what is meant by hoax news (Palupi, 2020). The circulation of hoax news is one of the things that threatens the nation. In Indonesia itself, with an already modern era, the spread of hoax news is still relatively large and easy to find anywhere. The spread of hoax news at this time is also supported by technological developments that make it easier for individuals who cannot be held responsible for what they have done (Majid, 2019). The hoax gave rise to uneasy feelings for the Indonesian people because there were many parties who felt that they had been harmed by the spread of the hoax news. It can be concluded that in 
using digital media it must be balanced with a critical mind so that it is not easily influenced and deceived by fake news (Priambodo, 2020).

\section{Theory of Truth and Its Role}

The level of digital literacy of the Indonesian people is still relatively low, which causes the Indonesian people to tend to assume all information is true without finding out the truth so that they are easily deceived by hoaxes (Maharani, 2019). In addition to digital literacy to fortify individuals from hoaxes, each individual must also improve their way of thinking to become more critical in receiving and sorting information. The way humans fix the frame of mind is also explained in the philosophy of science through the Theory of Truth before assuming an information is correct information or wrong information. In epistemology there are valid theories of truth, namely correspondence theory, coherence theory, pragmatic theory, consensus theory, and performative theory (Tukiran, 2020). Therefore, this study aims to examine the role of theories of truth in the philosophy of science related to testing information in countering hoaxes or fake news about COVID-19 in the perspective of the philosophy of science. However, this research also needs to be balanced with good digital literacy skills so that it can be fully implemented.

The research hypothesis is that in the theory of truth there are theories that can test the validity of information about COVID-19. Basically, philosophy can provide important benefits, namely thinking logically and critically which is the basic problem in the lack of digital literacy levels in Indonesia. Moreover, the era of globalization makes it easier for the world community to obtain and disseminate information from all corners of the world, including in Indonesia. However, with this easy access, there are some people who abuse it by spreading fake news or hoaxes. For example, in Indonesia there are still many cases of hoaxes that are spread and trusted by many people, especially when entering the era of the COVID-19 pandemic. In fact, the truth of information during a pandemic is something very important, especially related to health and the virus that causes this disease. The importance of this information is inseparable from efforts to educate all levels of society so that cooperation in reducing cases of transmission and death caused by the virus can be realized. Therefore, the researcher wants to prove whether the theory of philosophy of science can help the public in identifying and countering hoax news about COVID-19.

\section{METHODS}

The research was conducted using a descriptive verification method with a qualitative approach. The data of this study were taken from interviews conducted by the researcher. The target respondents are people in Surabaya with an age range of 25-40 years or what is often referred to as generation $\mathrm{Y}$ or millennials. The reason the researcher chooses people with these criteria is because the millennial generation is a generation that is easily influenced by hoaxes (Teenagers, 2020). The data obtained from this interview will be processed in several stages. According to Sidiq U (2019), there are three types of data analysis stages, namely 1) Data Reduction, 2) Data Exposure, 3) Conclusion Drawing/Verification. In the data reduction stage, the researcher will reduce the saturated samples from the interviews. Furthermore, the 
data will be presented at the data exposure stage using coding-verbatim techniques. The data that has been presented will then be drawn at the conclusion/verification stage. Researchers will classify the actions taken by respondents into the results of secondary data which has been collected using a literature study. The secondary data collection was obtained from 2 books, 37 articles, 1 website, and 1 reliable national survey report that has been published in the last 3 years and is related to research discussion topics such as the COVID-19 pandemic, digital literacy, hoaxes about COVID -19, and theories in the philosophy of science. After analyzing the data, the researchers will prove the hypothesis that the theory of truth in the philosophy of science can test the validity of information about COVID-19. The researchers proved this hypothesis by applying the findings regarding the function of truth theories to the respondents' experiences regarding the COVID-19 hoax.

The researchers got 4 respondents and will only use 3 because one of the 4 respondents is a saturated sample. Then, the focus is on question 5 and 6 only because these two questions can answer the research questions. The following is a list of questions we asked respondents during interviews.

Interview Questions:

1. Have you ever come across a hoax?

2. If so, where did you find the hoax?

3. Have you ever come across a hoax about COVID-19?

4. What is the form of the hoax?

5. What did you do when you found the COVID-19 hoax?

6. How do you know if the information is a hoax?

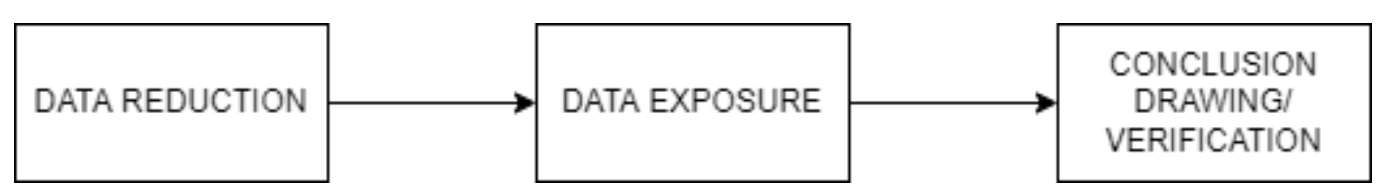




\section{RESULTS}

\section{Domain Analysis}

Question 5: What did you do when you found the COVID-19 hoax?

\begin{tabular}{|l|c|c|c|c|}
\hline \multicolumn{1}{|c|}{ INCLUDED TERM } & CODING & CATEGORY & SEMANTIC & $\begin{array}{c}\text { COVERING } \\
\text { TERM }\end{array}$ \\
\cline { 1 - 3 } AFFECTED BY HOAX & $5 . R 1-A$ & NEGATIVE & $\begin{array}{c}\text { REACTIONS } \\
\text { FROM }\end{array}$ & $\begin{array}{c}\text { HOAX } \\
\text { REGARDING } \\
\text { COVID-19 }\end{array}$ \\
\cline { 1 - 3 } $\begin{array}{l}\text { DOES NOT SPREAD } \\
\text { HOAX }\end{array}$ & 5. R2-B & POSITIVE & POSITIVE \\
\cline { 1 - 3 } HOAX NOT SPREAD & $5 . R 3-B$ & & \\
\hline
\end{tabular}

Question 6: How do you know the information is a hoax?

\begin{tabular}{|c|c|c|c|c|}
\hline INCLUDED TERM & CODING & CATEGORY & SEMANTIC & $\begin{array}{c}\text { TERM } \\
\text { COVERING }\end{array}$ \\
\hline $\begin{array}{l}\text { READ/CHECK THE } \\
\text { INFORMATION FROM } \\
\text { OFFICIAL SITE }\end{array}$ & 6.R1-A & $\begin{array}{l}\text { PERFORMATIVE } \\
\text { THEORY }\end{array}$ & \multirow[t]{8}{*}{$\begin{array}{l}\text { BRANCH } \\
\text { OF }\end{array}$} & \multirow[t]{8}{*}{$\begin{array}{l}\text { THEORY OF } \\
\text { TRUTH }\end{array}$} \\
\hline $\begin{array}{l}\text { CHECK THE } \\
\text { INFORMATION FROM } \\
\text { OFFICIAL } \\
\text { SITE }\end{array}$ & 6.R2-A & $\begin{array}{l}\text { PERFORMATIVE } \\
\text { THEORY }\end{array}$ & & \\
\hline $\begin{array}{l}\text { FIND ADDITIONAL } \\
\text { INFORMATION }\end{array}$ & 6.R2-B & $\begin{array}{c}\text { CORRESPONDENCE } \\
\text { THEORY }\end{array}$ & & \\
\hline $\begin{array}{l}\text { FIND ADDITIONAL } \\
\text { INFORMATION }\end{array}$ & 6.R3-B & $\begin{array}{c}\text { CORRESPONDENCE } \\
\text { THEORY }\end{array}$ & & \\
\hline $\begin{array}{l}\text { SEE THE NEWS FROM } \\
\text { RELIABLE SOURCES }\end{array}$ & 6.R2-C & $\begin{array}{l}\text { CONSENSUS } \\
\text { THEORY }\end{array}$ & & \\
\hline $\begin{array}{l}\text { COME TO THE PLACE } \\
\text { DIRECTLY }\end{array}$ & 6.R2-D & $\begin{array}{l}\text { PRAGMATIC } \\
\text { THEORY }\end{array}$ & & \\
\hline $\begin{array}{l}\text { ASK THE INFORMATION } \\
\text { TO SENDER }\end{array}$ & 6.R3-D & $\begin{array}{l}\text { PRAGMATIC } \\
\text { THEORY }\end{array}$ & & \\
\hline $\begin{array}{l}\text { COMPARE } \\
\text { INFORMATION }\end{array}$ & 6.R3-E & $\begin{array}{l}\text { COHERENCE } \\
\text { THEORY }\end{array}$ & & \\
\hline
\end{tabular}




\section{Network Coding}

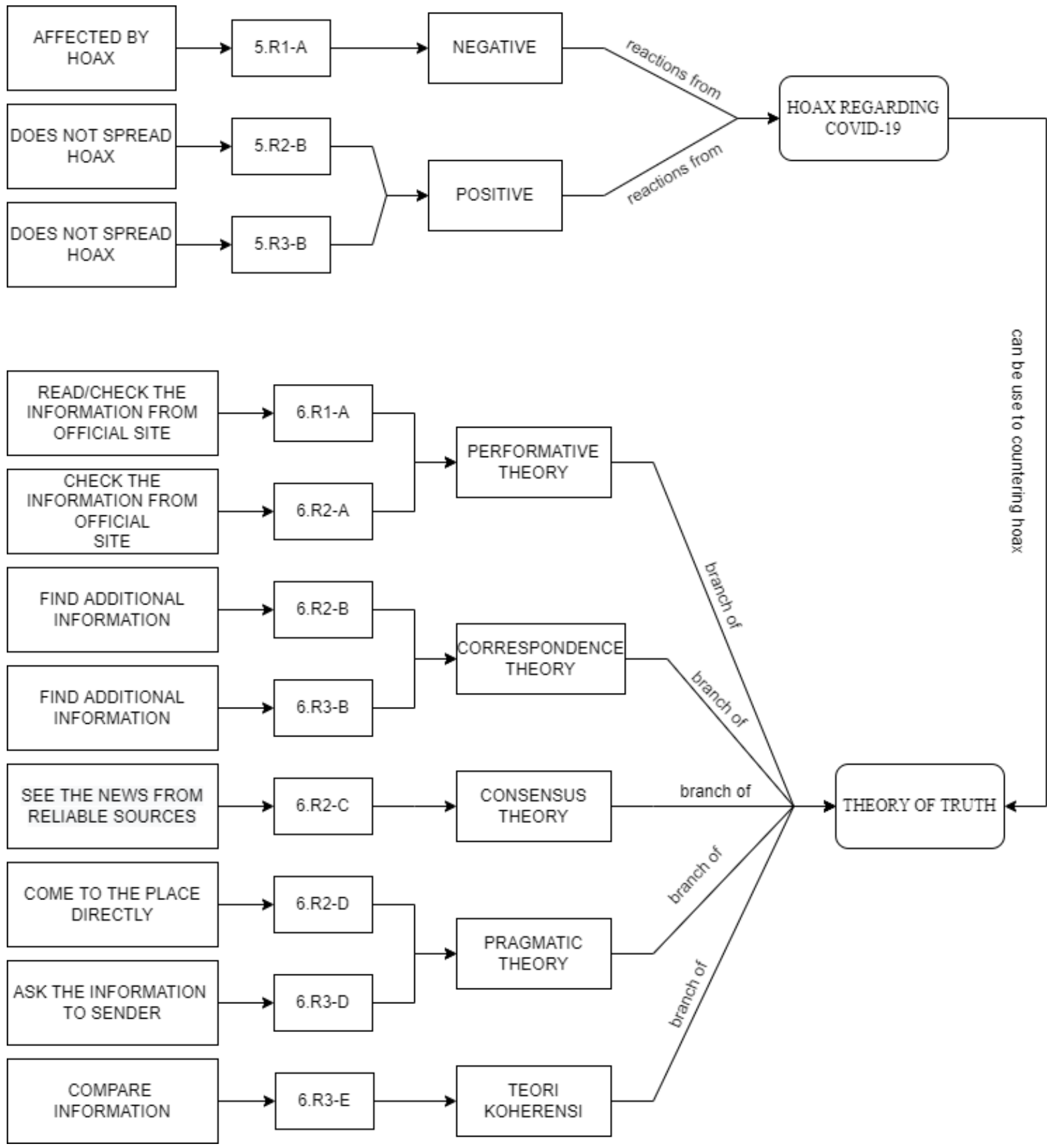

\section{DISCUSSION}

\section{The Role of Theory of Truth}

Theory of truth is a combination of two types of human knowledge, namely knowledge of objects called descriptions and knowledge of truth, namely a matter of the mind can form a knowledge of the truth with the truth in question is the coherence behind the facts (Rasuki, 2020). Humans can use their minds to think in finding the truth. However, according to Situmeang (2021), because not all existing truths are true, it is necessary to have a criterion to measure the truth. In the philosophy of science, the theory of truth is one of the 
materials that is focused on other than sources of knowledge (Padli and Mustofa, 2021). The theory of truth in the philosophy of science in fact has various forms in identifying the validity of a statement or information. There are five theories of truth that we found in this research, namely coherence theory, correspondence theory, pragmatic theory, consensus theory, and performative theory. The existence of various types and criteria of truth should no longer make people view the validity of statements or information as something that is difficult to prove.

\section{Coherence Theory}

The focus of coherence theory on truth is a coherent and consistent statement (Purwadhi, 2019). According to this theory, a true statement can be seen from the statements that have been stated previously. If the previous statement has been confirmed to be true, then the statement that will be stated later, as long as the statement is consistent and not contradictory, can be identified as a true statement.

It was also mentioned by (Indarti, 2020) that coherence theory tends to emphasize rational-logical truths and the workings of deductive thinking. The deductive way of thinking in question is a way of thinking that will draw specific conclusions from general statements. In other words, a statement that is true is a logical-rational consequence of a collection of statements that already exist and whose truth has been considered. However, it cannot be denied that the application of the coherence theory is a good thing, but a truth that is tested using the coherence theory will be more proven to be valid if another theory of truth, namely the correspondence theory, is also applied.

Based on the results of the interview, the application of the coherence theory was carried out by Respondent 3 . The respondent was able to identify that the information about COVID-19 he received was a hoax by comparing the information. This newly received information is then compared with information that has previously been received and has been verified. Our respondent found that there were contradictions in the two pieces of information so that he could ascertain the degree of truthfulness.

\section{Correspondence Theory}

Correspondence Theory is a branch of the theory of truth which argues, a true statement is a statement which corresponds to facts (Mahmudi \& Luthfi, 2020). Because of the importance of correspondence to facts, this theory indirectly encourages humans to be willing to carry out simple research that is within our knowledge to find the truth of a statement. So simply, the correspondence theory is a branch of the theory of truth that proves the validity of information by conducting simple research on the object of the problem to correspond (related) to the statement.

In the context of the hoax problem, the speed with which hoaxes are received and disseminated stems from someone's awareness of superficial conclusions about the information received (Swaradesy, 2020) or in other words, a lack of sense of logic. Meanwhile, in the context of finding logical truths that discuss epistemology, logic, and psychology, it is necessary to show the relationship or relationship between statements and 
objective reality (Hasan \& Pananrangi M, 2019). So, to express the consistency and the relationship between statements and facts or reality, the application of coherence and correspondence theory is a suitable combination in finding logical truths.

From the results of the interviews, the application of the correspondence theory was carried out by respondent 2 and respondent 3 . They applied this theory by seeking additional information. In the context of digital literacy, these 2 responses look for information or facts to ensure whether the information is correct and appropriate on the internet through an online search engine or more commonly called "Google".

\section{Pragmatic Theory}

According to Charles S. Peirce, pragmatic theory is an operational theory of meaning. This theory explains the concept of a topic, where the concept is a unitary unity that relates certain topics. In its continuation, pragmatism focuses more on an effort to integrate philosophy and science, so that philosophy can become scientific and effectively share values that are useful for human life. Pragmatic trust holders maintain that there are two fundamental things and must be observed in taking action, namely: the idea of a belief which is the basis for making a decision to take real action; and the target to be addressed (Astuti, 2020).

Those who study Pierce's philosophy of pragmatism think that the theory of meaning is Peirce's most influential participation. He took advantage of the pragmatic maxim to work on the clarity (clearness) and distinctness (distinctness) ideas. Clarity and difference are the two main studies in much modern writing on logic. An idea that is clearly defined as an idea that is easy to understand and will be known wherever it is found. Apart from that, there is no other understanding of this idea that gives rise to misunderstandings. When an idea is not successful in reaching this limit, the idea is said to be vague or abstract. There is also the existence of an idea is determined by the goodness of the description made. According to Peirce, logicians interpret an idea as whatever is contained in the definition or content of the idea. Ideas that have no distinction are called confusing (Sulaiman and Shofi'i, 2020).

Based on the interviews, the application of pragmatic theory was carried out by Respondents 2 and 3. Respondent 2 stated that he often visited vaccine locations to ensure the truth of information about vaccine procurement. This is done because often the amount of vaccine availability is not proportional to the number of people. Meanwhile, Respondent 3 stated that if the news is personal, it will be directly asked to the sender of the information. The operational action taken to reassure the information received is called the application of pragmatic theory.

\section{Consensus Theory Consensus}

Theory is an agreement within a group of truths that can form an explanation (Sholihah, 2020). From Jurgen Habermas, the truth is a claim of validity but also includes the agreement of all interlocutors without any of them who feel they are not considered in terms of sound with the speakers having a communicative rationale during discourse (Bufacchi, 2021). However, from Habermas' consensus theory, there are still two shortcomings, namely 
in terms of circularity and excess of context in his theory. In the case of circularity, what is emphasized is that consensus is not a conceptually inherent part of truth and does not provide criteria for applied truth. Therefore, the most desirable thing is agreement to provide some level of evidence support to find the truth. The second weakness is the context overload in Habermas' theory. The validity of his theory is beyond reason and cannot be defined within the framework of an idealized rational consensus, especially issues related to people's lives.

From the results of the interview, the consensus theory was applied by Respondent 2 . He looked for the same information again in reliable sources of information such as coverage websites 6 .

\section{Performative Theory}

JL Austin proposed performatives as utterances that are not constative, in the sense that they cannot be verified, famous for the reason that performatives are illocutionary, because they "do" the action as it is said or written. Austin's focus includes the environment or speech scene, in which the speaker and the situation must match the performative intent in order to function (Rak, 2021).

It is clear that performative utterances are not utterances that have the purpose of illuminating, revealing, or all utterances that have a descriptive nature, which have consequences for assessing whether or not the utterances or assumptions are uttered. Performative speech builds or produces action. For example, the saying, 'Watch out for the fierce dog!' What is spoken heavily will cause the result of an anxious attitude to the interlocutor, not because the meaning of the speech is right or wrong, in this example what is meant is that the speech partner does not know whether the dog is really fierce or not. The speech partner behaves this way because the speech is a warning or an act of warning (Saifudin, 2019).

From the results of the interview, the performative theory was applied by Respondent 1 and Respondent 2. They read again the information circulating on the official website for handling COVID-19 in Indonesia, namely covid.go.id by Respondent 1 and the official website of dr.soetomo, polrestabes surabaya, and healthy surabaya instagram account by respondent 2.

\section{CONCLUSION}

Based on the results of the data we got from interviews and literature studies, it can be concluded that to fortify oneself from hoaxes you can filter information using truth theories. The application of theories of truth can not only be applied by one method, but also by other methods because each branch of the theory of truth has its own function. Coherence theory (focusing on the continuity of new and existing information), correspondence theory (focusing on the correspondence of an information to facts), pragmatic theory (focusing on a belief to act and purpose), consensus theory (focusing on filtering portals or sources of information), and performative theory (focusing on doing an action based on what has been said). 
The existence of various types and criteria for truth should no longer make people view the validity of statements or information as something that is difficult to prove. The higher the validity of the information, the higher the validity of the information. The opposite can also be applied, the less the suitability of an information with theories of truth, then the validity of the information is also lower. With this scale, theories of truth have a role as a tool in filtering information about COVID-19.

Recommendations for further research need to be conducted research that can test the actual practice of applying truth theories in countering hoaxes in the community on a certain scale. This research has little chance of being applied by most Indonesians, given the low level of digital literacy and lack of willingness to find out the truth of information. 


\section{REFERENCES}

1. Herman, P. F. (2021). Pengembangan Media Video Berbasis Online Sebagai Upaya Pencegahan COVID-19 di Kabupaten Pamekasan (Doctoral dissertation, UNIVERSITAS AIRLANGGA).

2. Ciotti, M., Angeletti, S., Minieri, M., Giovannetti, M., Benvenuto, D., Pascarella, S., ... \& Ciccozzi, M. (2019). COVID-19 outbreak: an overview. Chemotherapy, 64(5-6), 215-223.

3. Salzberger, B., Glück, T., \& Ehrenstein, B. (2020). Successful containment of COVID-19: the WHO-Report on the COVID-19 outbreak in China.Infection 48, $151-153$.

4. Abdi, M. (2020). Coronavirus disease 2019 (COVID-19) outbreak in Iran: Actions and problems. Infection Control \& Hospital Epidemiology, 41(6), 754-755.

5. Etikasari, B., Puspitasari, T. D., Kurniasari, A. A., \& Perdanasari, L. (2020). Sistem Informasi Deteksi Dini Covid-19. Jurnal Teknik Elektro dan Komputer, 9(2), 101-108.

6. Nursofwa, R. F., Sukur, M. H., \& Kurniadi, B. K. (2020). Penanganan Pelayanan Kesehatan di Masa Pandemi Covid-19 dalam Perspektif Hukum Kesehatan. Inicio Legis Fakultas Hukum Universitas Trunojoyo Madura, 1(1).

7. Yunus, N.R., Rezki, A. (2020). Kebijakan Pemberlakuan Lockdown sebagai Antisipasi Penyebaran Corona Virus Covid-19. SALAM; Jurnal Sosial \& Budaya Syar-i, 7(3), 227.

8. Elgaputra, R. R., Sakti, E. Y. A., Widyandri, D. B., Azhari, A. R., Renatta, C., Rainasya, K., ... \& Musta'ina, S. (2020). Implementasi Sosialisasi Covid-19 dalam Upaya Meningkatkan Kesadaran masyarakat terhadap Protokol Kesehatan di Kota Jakarta. Jurnal Layanan Masyarakat (Journal of Public Services), 4(2), 423-433.

9. Setiati, S., \& Azwar, M. K. (2020). COVID-19 and Indonesia. Acta Medica Indonesiana, 52(1), 84-89.

10. Nurislaminingsih, R. (2020). Layanan Pengetahuan tentang COVID-19 di Lembaga Informasi. Tik Ilmeu: Jurnal Ilmu Perpustakaan dan Informasi, 4(1), 19-38.

11. Maulana, R. A. (2020). Kemampuan Literasi Digital di Kalangan Pemilih Kota Pemula 2020 (Doctoral dissertation, UNIVERSITAS AIRLANGGA).

12. Marwuni, W. T. (2021). Peran Literasi Digital sebagai Upaya Preventif untuk Penangkal Hoaks di Era Modernisasi 4.0. Jurnal Implementasi, 1(2), 154-161.

13. Kementerian Informatika dan Komunikasi. (2020). Status Literasi Digital Indonesia 2020 Hasil Survei di 34 Provinsi. Kementerian Informatika dan Komunikasi, Jakarta. 2020.

14. Harisanty, D., Srirahayu, D. P., Anna, N. E. V., Mannan, E. F., Anugrah, E. P., Nurpratama, M. R., \& Dina, N. Z. (2021). Socialization of Digital Literacy Education to Anticipate Hoax News. Darmabakti Cendekia: Journal of Community Service and Engagements, 3(1), 33-37.

15. Siste, K., Hanafi, E., Lee Thung Sen, H. C., Adrian, L. P. S., Limawan, A. P., Murtani, B. J., \& Suwartono, C. (2020). The Impact of Physical Distancing and Associated Factors towards Internet Addiction among Adults in Indonesia during COVID-19 Pandemic: a nationwide web-based study. Frontiers in psychiatry, 11 .

16. Barni, M. (2020, September). Pemanfaatan Internet sebagai Bahan Pengayaan bagi Mahasiswa dalam Perkuliahan. In Proceeding Antasari International Conference (Vol. 1, No. 1).99-108. 
17. Ummah, A. H., \& Kurniawan, A. (2020). Literasi Digital dan Peran Strategis Net Generation dalam Membangun Konten Positif di Media Sosial. INTEGRITAS: Jurnal Pengabdian, 4(2), 170-181.

18. Putri, N. F., Vionia, E., \& Michael, T. (2020). Pentingnya Kesadaran Hukum dan Peran Masyarakat Indonesia dalam Menghadapi Penyebaran Berita Hoax COVID-19. Media Keadilan: Jurnal Ilmu Hukum, 11(1), 98-111.

19. Website Resmi Penanganan COVID-19. (2021, 25 June). [SALAH] Resep Obat Untuk Pasien Covid-19 - Hoax Buster | Covid19.go.id. Diakses 27 November, 2021, dari covid19.go.id website: https://covid19.go.id/p/hoax-buster/salah-resep-obat-untuk-pasien-covid-19

20. Rahayu, R. N., \& Sensusiyati. (2020). Analisis Berita Hoax COVID - 19 di Media Sosial di Indonesia. Jurnal Ekonomi, Sosial \& Humaniora, 1(09), 60-73.

21. Wardhana, D. (2020). Kajian Kebijakan dan Arah Riset Pasca-Covid-19. The Indonesian Journal of Development Planning, IV(2), 223-239.

22. Palupi, M. T. (2020). Hoax: Pemanfaatannya sebagai Bahan Edukasi di Era Literasi Digital dalam Pembentukan Karakter Generasi Muda. Jurnal Skripta, 6(1), 1-12

23. Majid, A. (2019). Fenomena Penyebaran Hoax dan Literasi Bermedia Sosial Lembaga Mahasiswa Universitas Muslim Indonesia. Jurnal Komodifikasi, 8, 228-239

24. Priambodo, A. W. (2020). Literasi Digital Warga Surabaya Saat Pandemi Covid-19 (Studi Deskriptif Mengenai Tingkat Kompetensi Literasi Digital Warga Surabaya saat Pandemi Covid-19) (Doctoral dissertation, UNIVERSITAS AIRLANGGA).

25. Maharani, C. S. E. (2019). Literasi Digital Ibu Rumah Tangga di Surabaya sebagai Digital Imigrant dalam Penggunaan Media Sosial (Doctoral dissertation, Universitas Airlangga).

26. Tukiran, M. (2020). Filsafat Manajemen Pendidikan. PT Kanisius.

27. Remaja, I. N. G., \& Ardana, D. M. J. (2020). Pengamanan Informasi Dalam Rangka Mengawal Generasi Milenial Tolak Ancaman Berita Hoax. Jnana Karya, 1(01), 10.

28. Sidiq U, C. M. (2019). Metode Penelitian Kualitatif di Bidang Pendidikan. Ponorogo: CV Nata Karya.

29. Rasuki, R. (2020). Problem Filsafat yang Tidak Tuntas: Realitas, Universalitas, Kebenaran: Studi Analisa tentang Realitas, Universalitas dan Kebenaran. Jurnal Kariman, 8(1), 67-78.

30. Situmeang, I. R. V. O. (2021). Hakikat Filsafat Ilmu dan Pendidikan dalam Kajian Filsafat Ilmu Pengetahuan. IKRA-ITH HUMANIORA: Jurnal Sosial dan Humaniora, 5(1), 1-17.

31. Padli, M., \& Mustofa, M. (2021). Kebenaran dalam Perspektif Filsafat serta Aktualisasinya dalam Men-Screening Berita. Jurnal Filsafat Indonesia, 4(1), 78-88.

32. Purwadhi. (2019). Peranan Ilmu-ilmu Sosial dalam Menggapai Kebenaran Ilmiah. SOSIOHUMANIKA: Jurnal Pendidikan Sains Sosial Dan Kemanusiaan, 12(1), 69-80.

33. Indarti, N. (2020). Hakikat Ilmu Pengetahuan dan Relasinya dengan Teori Kebenaran dalam Perspektif Tafaqquh Fi Al-Diin. Jurnal Al-Makrifat, 5(1), 1-30.

34. Mahmudi, W. L., \& Luthfi, F. (2020). Kebenaran Ilmiah (Perspektif Ilmu Ekonomi Islam). Orbith: Majalah Ilmiah Pengembangan Rekayasa Dan Sosial, 16(2), 139-146.

35. Swaradesy, R. (2020). Hoaks dan Logika Bahasa: Fenomena Niat Baik Dimanfaatkan untuk Tipu Muslihat. Waskita: Jurnal Pendidikan Nilai dan Pembangunan Karakter, 2(1), 47-56. 
36. Hasan, K., \& A. PANANRANGI M. (2019). Memahami Kebenaran dalam Perspektif Filsafat Administrasi. Meraja Journal, 2(1), 57-68.

37. Astuti, E. T. (2020). Filsafat Ilmu Pengetahuan sebagai Arah Pengembangan Berpikir yang Konstruktif: Telaah Pemikiran Pragmatis Charles S. Peirce dan Kontribusinya dalam Pembelajaran Sains Pendidikan Dasar Islam. At-Tajdid: Jurnal Ilmu Tarbiyah, 9(1), 1-16.

38. Sulaiman, A., \& Shofi'i, E. N. (2020). Living al-Qur'an dan Hadis: Pendekatan Filsafat Pragmatisme Charles Sanders Peirce. Asyahid Journal of Islamic and Quranic Studies (AJIQS), 2(2).

39. Sholihah, Q. (2020). Pengantar Metodologi Penelitian. Universitas Brawijaya Press.

40. Bufacchi, V. (2021). Truth, Lies and Tweets: A Consensus Theory of Post-truth. Philosophy \& Social Criticism, 47(3), 347-361.

41. Rak, J. (2021). Performativity. In Oxford Research Encyclopedia of Literature.

42. Saifudin, A. (2019). Teori Tindak Tutur dalam Studi Linguistik Pragmatik. Lite: Jurnal Bahasa, Sastra, dan Budaya, 15(1), 1-16. 


\section{ATTACHMENT}

- Analysis Coding-Verbatim

Question 5: What did you do when you found the COVID-19 hoax?

\begin{tabular}{|c|c|c|c|c|c|}
\hline Respondent & $\begin{array}{l}\text { Interview } \\
\text { Transcript } \\
\text { Results }\end{array}$ & Verbatim & $\begin{array}{c}\text { Coding } \\
\text { (Technic } \\
\text { al) }\end{array}$ & $\begin{array}{c}\text { Compaction } \\
\text { of Facts }\end{array}$ & $\begin{array}{c}\text { Coding } \\
\text { (Substantive) }\end{array}$ \\
\hline $\begin{array}{l}\text { Respondent } \\
1\end{array}$ & $\begin{array}{l}\text { Hoax about } \\
\text { eating boiled } \\
\text { eggs at } 3 \text { o'clock } \\
\text { can be strong } \\
\text { from COVID-19 } \\
\text { the same as } \\
\text { about vaccines } \\
\text { that are said to be } \\
\text { dangerous which } \\
\text { have been } \\
\text { influenced by the } \\
\text { egg hoax. One of } \\
\text { my family } \\
\text { members told me } \\
\text { to eat boiled eggs } \\
\text { at } 3 \text { o'clock in } \\
\text { the morning. } \\
\text { When it comes to } \\
\text { vaccines, I didn't } \\
\text { believe in } \\
\text { vaccines, but } \\
\text { now thank God } \\
\text { I've been } \\
\text { vaccinated with } 2 \\
\text { doses }\end{array}$ & $\begin{array}{l}\text { Affected by the } \\
\text { hoax of } \\
\text { "Eating boiled } \\
\text { eggs at } 3 \text { am } \\
\text { can ward off } \\
\text { the COVID-19 } \\
\text { virus" and did } \\
\text { not believe in } \\
\text { vaccines, but } \\
\text { now already } \\
\text { got } 2 \text { doses of } \\
\text { the vaccine. }\end{array}$ & 5.R1 & $\begin{array}{l}\text { Affected by } \\
\text { hoax. }\end{array}$ & 5.R1-A \\
\hline $\begin{array}{l}\text { Respondent } \\
2\end{array}$ & $\begin{array}{l}\text { I don't think so, } \\
\text { I'm not the type } \\
\text { of person who } \\
\text { likes to spread } \\
\text { uncertain } \\
\text { information. }\end{array}$ & $\begin{array}{l}\text { Do not } \\
\text { participate in } \\
\text { spreading } \\
\text { hoaxes because } \\
\text { they are not the } \\
\text { type of people } \\
\text { who like to } \\
\text { spread } \\
\text { uncertain } \\
\text { information. }\end{array}$ & 5.R2 & $\begin{array}{l}\text { Does not } \\
\text { spread } \\
\text { hoax. }\end{array}$ & 5.R2-B \\
\hline
\end{tabular}




\begin{tabular}{|l|l|l|l|l|l|}
\hline $\begin{array}{l}\text { Respondent } \\
3\end{array}$ & $\begin{array}{l}\text { If I know it's not } \\
\text { true, I usually } \\
\text { just skip it. }\end{array}$ & $\begin{array}{l}\text { Does not } \\
\text { spread hoax } \\
\text { when I know } \\
\text { the truth. }\end{array}$ & 5.R3 & $\begin{array}{l}\text { Does not } \\
\text { spread } \\
\text { hoax. }\end{array}$ & 5.R3-B \\
\hline
\end{tabular}

Note:

- 5: Question Number

- R: Respondent

- A: Respondent affected by hoax

- B: Respondent does not spread hoaxes

Question 6: How do you know the information is a hoax?

\begin{tabular}{|c|c|c|c|c|c|}
\hline Respondent & $\begin{array}{c}\text { Interview } \\
\text { Transcript } \\
\text { Results }\end{array}$ & Verbatim & $\begin{array}{c}\text { Coding } \\
\text { (Technic } \\
\text { al) }\end{array}$ & $\begin{array}{l}\text { Compaction } \\
\text { of Facts }\end{array}$ & $\begin{array}{c}\text { Coding } \\
\text { (Substantive) }\end{array}$ \\
\hline $\begin{array}{l}\text { Respondent } \\
1\end{array}$ & $\begin{array}{l}\text { - After I read } \\
\text { the news about } \\
\text { eggs on the } \\
\text { government's } \\
\text { google website, } \\
\text { which was } \\
\text { COVID-19 } \\
\text { (covid19.go.id) } \\
\text { it turned out to } \\
\text { be a hoax. } \\
\text { Hard-boiled } \\
\text { eggs don't make } \\
\text { people immune } \\
\text { to corona. }\end{array}$ & $\begin{array}{l}\text { - Read the } \\
\text { news on the } \\
\text { official } \\
\text { website for } \\
\text { handling } \\
\text { COVID-19 } \\
\text { which } \\
\text { confirmed } \\
\text { that the } \\
\text { information } \\
\text { was a hoax. }\end{array}$ & 6.R1 & $\begin{array}{l}\text { Read/check } \\
\text { the } \\
\text { information } \\
\text { from the } \\
\text { official site. }\end{array}$ & 6.R1-A \\
\hline \multirow[t]{4}{*}{$\begin{array}{l}\text { Respondent } \\
2\end{array}$} & \multirow{4}{*}{$\begin{array}{l}\text { If looking for } \\
\text { more } \\
\text { information, } \\
\text { maybe yes, on } \\
\text { google and I } \\
\text { also was } \\
\text { assisted by my } \\
\text { relatives in } \\
\text { finding the truth } \\
\text { of the } \\
\text { information. } \\
\text { - That's right, I } \\
\text { will trust the } \\
\text { source of the } \\
\text { news from } \\
\text { Liputan } 6 \text { more }\end{array}$} & \multirow{4}{*}{$\begin{array}{l}\text { - Look for the } \\
\text { information } \\
\text { again on the } \\
\text { internet to } \\
\text { make sure the } \\
\text { information is } \\
\text { correct. } \\
\text { - Check the } \\
\text { information } \\
\text { from reliable } \\
\text { sources such } \\
\text { as the website } \\
\text { Liputan } 6 . \\
\text { - Take action } \\
\text { by going } \\
\text { directly to the }\end{array}$} & \multirow[t]{4}{*}{ 6.R2 } & $\begin{array}{l}\text { Find } \\
\text { additional } \\
\text { information. }\end{array}$ & 6.R2-B \\
\hline & & & & $\begin{array}{l}\text { See the news } \\
\text { from reliable } \\
\text { sources. }\end{array}$ & 6.R2-C \\
\hline & & & & $\begin{array}{l}\text { Come to the } \\
\text { place directly. }\end{array}$ & 6.R2-D \\
\hline & & & & $\begin{array}{l}\text { Check the } \\
\text { information } \\
\text { from the } \\
\text { official site. }\end{array}$ & 6.R2-A \\
\hline
\end{tabular}




\begin{tabular}{|c|c|c|c|c|c|}
\hline & $\begin{array}{l}\text { than the } \\
\text { WhatsApp } \\
\text { group messages } \\
\text { with unclear } \\
\text { sources. } \\
\text { - Once (make } \\
\text { sure the news } \\
\text { goes to related } \\
\text { places), I often } \\
\text { run out of } \\
\text { vaccine quota. } \\
\text { Many } \\
\text { procurements } \\
\text { for the } \\
\text { implementation } \\
\text { of vaccines have } \\
\text { very little quota, } \\
\text { not proportional } \\
\text { to the number of } \\
\text { enthusiasts. } \\
\text { - I've checked } \\
\text { through official } \\
\text { sites such as the } \\
\text { dr. Soetomo } \\
\text { hospital site, the } \\
\text { Surabaya } \\
\text { Polrestabes site, } \\
\text { and the } \\
\text { Instagram } \\
\text { account of } \\
\text { Surabaya Sehat. }\end{array}$ & $\begin{array}{l}\text { place of } \\
\text { implementati } \\
\text { on of the } \\
\text { vaccine. } \\
\text { - Check on } \\
\text { the official } \\
\text { website } \\
\text { directly, such } \\
\text { as dr.soetomo, } \\
\text { surabaya } \\
\text { polrestabes, } \\
\text { and surabaya } \\
\text { sehat } \\
\text { instagram } \\
\text { account. }\end{array}$ & & & \\
\hline \multirow[t]{3}{*}{$\begin{array}{l}\text { Respondent } \\
3\end{array}$} & \multirow{3}{*}{$\begin{array}{l}\text { - If the } \\
\text { information has } \\
\text { a personal } \\
\text { influence } \\
\text { (prescribing } \\
\text { drugs), I usually } \\
\text { ask the sender } \\
\text { directly. } \\
\text { - For general } \\
\text { information } \\
\text { (regarding } \\
\text { COVID-19), I } \\
\text { can search on } \\
\text { google whether } \\
\text { this is true or }\end{array}$} & \multirow{3}{*}{$\begin{array}{l}\text { - Take direct } \\
\text { action by } \\
\text { asking about } \\
\text { COVID-19 } \\
\text { drug } \\
\text { prescriptions } \\
\text { to the sender } \\
\text { of } \\
\text { information. } \\
\text { - Look for the } \\
\text { information } \\
\text { again on the } \\
\text { internet to } \\
\text { make sure the } \\
\text { information is }\end{array}$} & \multirow[t]{3}{*}{ 6.R3 } & $\begin{array}{l}\text { Ask the } \\
\text { information } \\
\text { to the sender. }\end{array}$ & 6.R3-D \\
\hline & & & & $\begin{array}{l}\text { Find } \\
\text { additional } \\
\text { information. }\end{array}$ & 6.R3-B \\
\hline & & & & $\begin{array}{l}\text { Compare } \\
\text { information. }\end{array}$ & 6.R3-E \\
\hline
\end{tabular}




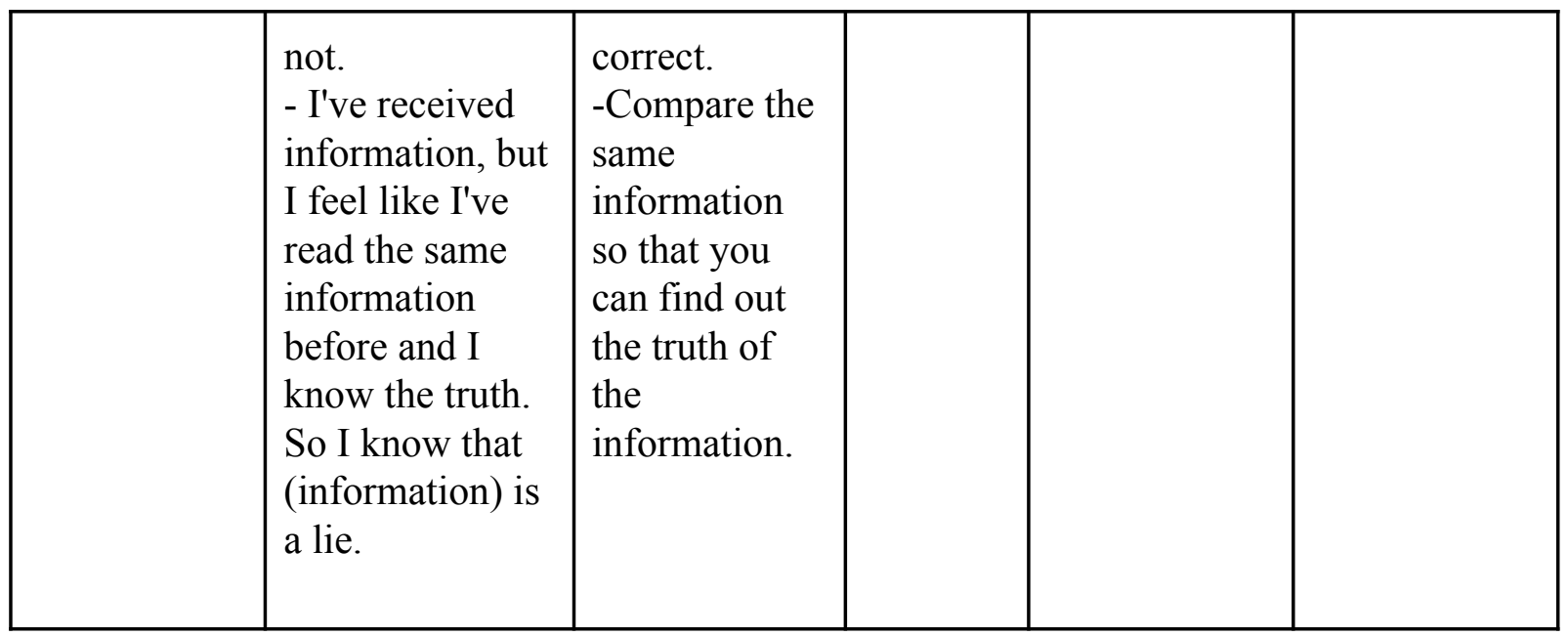

Note:

- 6: Question number

- R: Respondent

- A: Read/check the information from the official site

- B: Find additional information

- C: See the news from reliable sources

- D: Do action

- E: Compare information 